\title{
複合材料積層板中の多重層間剥離伝播挙動の 非線形有限要素解析
}

\author{
間 島 理*1, 末益 博志*2 \\ (1999 年 10 月 12 日受付)
}

\author{
A Nonlinear Finite Element Analysis of Multiple Delamination \\ Propagation in Composite Laminates
}

\author{
Osamu Majima*1 and Hiroshi Suemasu*2
}

(Received October 12, 1999)

\begin{abstract}
Propagation process of multiple penny-shape interlaminar delaminations in circular axisymmetric nonlinear plates under a quasi-static transverse load, which is an idealized problem of damage accumulation in composite laminates due to low velocity impact loading, is numerically studied through a finite element analysis. A fracture element, which was proposed to simulate the crack propagation (Majima \& Suemasu, 1999), is modified for elements with mid-node. The condition for crack propagation is also changed to make the convergence of the solution with element size smoother. Both failures related to strength and the fracture mechanical instability are possible to be considered by using the present element. The element is applied to a fundamental problem of fracture mechanics. The solution converges quickly with the decrease of element size and the results are consistent with the theoretically predicted solution. The sufficiently accurate solution is obtained even with the fairly rough element division. Then the element is used to simulate the propagation of multiple delaminations in a composite laminate, considering nonlinearity due to finite deflection. The early stages of the damage propagation depend on the initial delamination size. The finite element results are consistent with the failure process inferred from the energy release rate distribution theoretically obtained in the precedent study (Suemasu \& Majima, 1998).
\end{abstract}

\section{1. 序}

\section{論}

炭素繊維複合材料（CFRP）を始めとする複合材料積 層構造は比強度, 比剛性が極めて大きく, 航空・宇宙分 野を始めとする多くの分野で広く使用されている.これ らの複合材料構造が異物衝突等による衝撃荷重を受ける とマトリックスクラック, 層間剥離等の損傷を発生し, その力学的特性, 特に圧縮強度が大きく低下する (CAI)．この低下した圧縮強度が複合材料構造の設計荷 重を大きく支配する.

複合材料積層板の衝撃損傷のメカニズムを明らかにす

*1,*2 上智大学理工学部機械工学科（102-8554 東京都千 代田区紀尾井町 7-1)

Department of Mechanical Engineering, Faculty of Science and Technology, Sophia University, 7-

1, Kioi-cho, Chiyoda-ku, Tokyo 102-8554 Japan

${ }^{* 1}$ 助手 Research Associate, *2教授 Professor
るため現在まで多くの実験的研究がなされてきた ${ }^{1 \sim 6)}$. その結果, 層間剝離はマトリックスクラックを伴って多 重層間剥離の形で発生し, 衝撃エネルギーがあるレベル を超えると損傷領域は衝撃エネルギーにほほ比例して増 えること, また層間剝離のサイズは衝撃面から反対側の 面に向かって大きくなること等が明らかにされている. 一方において, これらの衝撃損傷は積層板の積層構成, 形状・寸法などの影響を受けるので, 実験的研究による データの蓄積のみでなく, 解析的・数值的手法によって 衝撃損傷のメカニズムを統一的に解明しょうとする試み もなされている．積層板が低速衝撃荷重を受ける場合， その応答は静荷重下での応答と類似している年)ので静 荷重下での損傷蓄積メカニズムを解明することが行われ ている. 著者ら ${ }^{8,9)}$ は線形及び非線形軸対称積層板の損 傷蓄積のプロセスを平板曲げ理論に基づいて理論的に解 明し，多重層間剝離のメカニズムを説明することができ た.しかし衝撃等の動的な問題を取り扱うためにはクラ 
ック進展を考慮した数值的手法が必要である，損傷力学 に基づいて破損プロセスを解明する試みが多くの研究者 によってなされている ${ }^{10 \sim 13)}$ が, 層間剝離の損傷進展の メカニズムを解明するためには破壊力学的取り扱いが必 要と考えられる. Sankar 等 ${ }^{14)}$ は有限要素法を用いて破 壊力学に基づき片持ち梁の動的な剶離伝播問題を取り扱 った. Jih ら ${ }^{15)}$, Razi ら ${ }^{16)}$, Liu ら ${ }^{17)}$, Kamiya ら ${ }^{18)}$ は エネルギー解放率を用いて剥離の進展を予測できること を示している.

積層板の低速衝撃損傷問題を準静的な問題として取り 扱う場合には豩離クラックの安定・不安定の判断はクラ ック先端でのエネルギー解放率を用いて破壊力学的に予 測することが可能である。しかし動的な衝撃問題として 取り扱うためにはクラック進展に伴って破面を形成する ために消費されるエネルギーを考慮する必要がある. Crisfield ら ${ }^{19)}$ は材料の強度とクラック先端部のエネル ギー解放率を考慮したインターフェイス要素を提案して クラック進展のシミュレーションを試みたが, クラック 進展後の特性を明確に定めていないため破面の開口, 閉 鎖が問題となる衝撃損傷問題に適用するためには困難を 伴う.

著者らは前報20,21)において強度と破壊力学的特性の 両方を考慮した破壊要素を有限要素解析に導入してクラ ック面形成のために消費されるエネルギーを考慮するこ とが可能な解析手法を提案し, 手法の妥当性を確認し た。しかしこの手法では妥当な結果を得るためには有限 要素分割を非常に密にする必要があり, 衝撃問題に適用 するためにはより効率的な解析手法が望まれる。そこで 本解析では問題を準静的問題に限定して前報の手法を中 間節点を有する高次有限要素に拡張し，またクラック伝 播の判定を有限要素単位で行うように改善することによ り解析の効率化を図る. 本解析手法を準静的な集中荷重 を受ける軸対称積層板の多重層間剝離伝播問題に適用 し，幾何学的非線形性を考慮した解析を行った。

\section{2. クラックの発生と進展の有限}

\section{要素法によるモデル化}

積層板中における損傷の発生と進展を適切にシミュレ ートするためには材料の強度と破壊力学的特性を共に考 慮できるようなモデル化が必要と考えられる. そこで, クラック面に作用する力が材料の強度に達するか, また はそれによってなされる仕事が材料の破壞鞁性に達する と切れるような非線形バネを有限要素解析に導入する. これにより材料強度に達する応力が生じる領域でのク

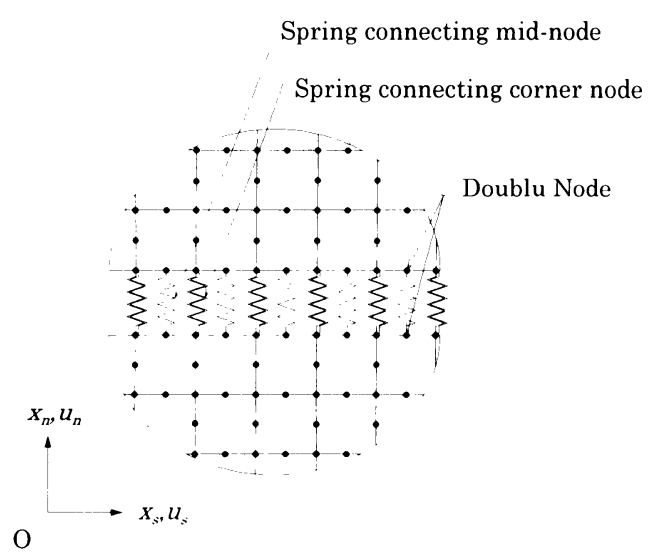

Fig. 1 Fracture elements in an expected crack plane.

ラック発生のモデル化が可能となる。この考え方は Dugdale-Barenbradt の破壊モデルの有限要素法への拡 張と考えることができょう.

クラックが進展すると予想される部分に無荷重状態で 同じ座標を持つ節点を 2 個設定し (2 重節点), その間 にFig. 1 に示すように引張, 剪断両方向に対して非線 形バネを取り付ける。 バネを取り付ける有限要素の境界 の法線方向, 接線方向を各々 $x_{n}$ 軸, $x_{s}$ 軸とする. 図に は簡単化のために引張方向のバネのみを示した.この非 線形バネの特性は本来材料の非弾性的な変形特性から定 められるものであるが, ここでは非弾性的な変形が力と 共に増加すると考えて 2 重節点間に働く力がその相対変 位のべき乗に比例すると仮定する．節点 $i$ に取り付けら れたバネの $x_{n}, x_{s}$ 方向のバネ力 $F_{n i}, F_{s i}$ と相対変位 $\Delta u_{n i}, \Delta u_{s i}$ の関係は,

$$
\begin{array}{ll}
F_{n i}= \begin{cases}k_{c i} \Delta u_{n i} & \left(\Delta u_{n i}<0\right) \\
k_{t i}\left(\Delta u_{n i}\right)^{\alpha} & \left(0 \leq \Delta u_{n i}<\Delta u_{n i c}\right)\end{cases} \\
F_{s i}= \pm k_{s i}\left|\Delta u_{s i}\right|^{\beta} & \left(\left|\Delta u_{s i}\right|<\Delta u_{s i c}\right)
\end{array}
$$

と表される.ここで $k_{t i}, k_{s i}, \alpha$ 及び $\beta$ は物体の引張及 び剪断の非弾性的な変形特性から決定されるパラメー 夕, $\Delta u_{n i c}, \Delta u_{s i c}$ は臨界相対変位である. $\Delta u_{n i}<0 て ゙ の$ $k_{c i} \Delta u_{n i}$ は材料が圧縮応力下で重なり合うことを防ぐた めに導入されたバネである. $k_{c i}$ には要素間の重なりが 要素の変位に比べて十分小さくなるような正の大きな值 を与える。

破断時のバネに発生する力は, 材料の引張強度 $\sigma_{c}$, 剪断強度 $\tau_{c}$ 及びバネを取り付ける要素の断面積 $A$ を用 いて次のように表せる。 


$$
\begin{aligned}
& F_{n i c}=k_{t i}\left(\Delta u_{n i c}\right)^{\alpha}=\sigma_{c} p_{i} A \\
& F_{s i c}=k_{s i}\left(\Delta u_{s i c}\right)^{\beta}=\tau_{c} p_{i} A
\end{aligned}
$$

ここで $p_{i}$ は有限要素の形状関数に依存して決まる係数 であり，例えば 4 節点要素では $1 / 2$ ，中間節点を有する 8 節点アイソパラメトリック要素（以下単に 8 節点要素 と呼ぶ）では頂点の節点のバネに対して $1 / 6$, 中間節点 のバネに対して $4 / 6$ である。また $k_{c i}$ に関しても同様の 重みを乗ずる必要がある。

破断までにバネに蓄えられる変形エネルギーが破壊䩲 性に等しいとすると

$$
\begin{aligned}
& \int_{0}^{\Delta u_{n i c}} k_{t i} x^{\alpha} d x=G_{\mathrm{I}} p_{i} A \\
& \int_{0}^{\Delta u_{s i c}} k_{s i} x^{\beta} d x=G_{\mathrm{II} c} p_{i} A
\end{aligned}
$$

$\alpha, \beta$ の值が与えられると, 式 (3), (4) よりバネの臨 界相対変位及びバネ定数が決まる。

$$
\begin{array}{ll}
\Delta u_{n i c}=\frac{(\alpha+1) G_{c}}{\sigma_{c}} & \Delta u_{s i c}=\frac{(\beta+1) G_{I_{c}}}{\tau_{c}} \\
k_{t i}=\frac{\sigma_{c}^{\alpha+1} p_{i} A}{\left\{(\alpha+1) G_{c}\right\}^{\alpha}} & k_{s i}=\frac{\tau_{c}^{\beta+1} p_{i} A}{\left\{(\beta+1) G_{I_{c}}\right\}^{\beta}}
\end{array}
$$

相対変位 $\Delta u_{n i}$ または $\Delta u_{s i}$ が臨界相対変位を超えたと き材料は破壊したものと判定し引張及び剪断変形に対す る抵抗をゼロとする．ただし破面での接触問題を考慮し て圧縮変形に対する抵抗は破壊前と変わらないものとす る. 即ち，破壊後のバネ要素特性を次式で表す。

$$
\begin{aligned}
& F_{n i}=\left\{\begin{array}{cc}
k_{c i} \Delta u_{n i} & \left(\Delta u_{n i}\right)<0 \\
0 & \left(\Delta u_{n i}\right) \geq 0
\end{array}\right. \\
& F_{s i}=0
\end{aligned}
$$

これらの非線形バネは有限要素単位で取り付けられて いるものとする．即ち，クラックの進展が予想される面 に沿って隣接する要素間の節点には両方の要素に対応し たバネが取り付けられることになる．従って要素の大き さが同じ場合には上下の節点間には式（6）で示した值 の 2 倍の剛性が与えられることになる。ある有限要素を 考えた場合，この要素に取り付けられたバネのいずれか が破壊条件に達したときその有限要素に対応する面全体 が破断すると仮定し，その有限要素に取り付けられた全 てのバネを切断する。

本手法において破壊要素の特性は本来材料の非弾性特 性から決定すべきものであるがそれらを厳密に決定する

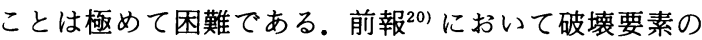
特性を式（1）（2）のように仮定する場合には破断に至 るまでの変形エネルギーが材料の破壊靭性に等しくなる ように破壊要素の特性を決定すれば全体的な解の傾向に 及ほす $\alpha$ または $\beta$ の值の影響は小さいことを示した。
また破壊要素はクラック先端部の局所的非弾性変形のみ をシミュレートし, 弾性変形は通常の有限要素によりシ ミュレートされるものと考えれば破壊要素は弾性域, 即 ち応力がある值になるまでできるだけ変形しない方が良 いので $\alpha, \beta$ の值は小さい值であることが望ましい. 本 解析では数值計算上の困難さをも考慮し， $\alpha=\beta=0.1$ として解析を行った.このときの荷重変位関係は剛完全 塑性に近いものになっており，この程度の值が妥当なも のと考えている。なお，実際の数値計算においてはバネ の相対変位が極めて小さい部分で荷重変位曲線の勾配が 非常に大きくなることを避けるために曲線の立ち上がり 部分において直線近似を行った。

以上に示した引張及び剪断に対する非線形バネ要素か らなるモデルを汎用の FEM プログラムに組み込む。 FEM プログラムとしては任意の荷重・変位履歴を持つ 非線形バネを容易にユーザサブルーチンとして定義でき ることから MARCを使用する。

\section{3. 等方性無限物体中の円形クラックの進展}

本手法によるモデル化の妥当性を確認するために等方 性無限物体中に Fig. 2 に示すような円形クラックがあ り，その内面の一部に一様圧力を受ける場合のクラック 進展問題を解析する。この問題は材料が線形弾性の場合 には厳密解が存在し, 荷重一定のときクラック進展に伴 いエネルギー解放率が減少していく問題でありクラック の安定成長が実現できる。このときクラック先端の応力 場は純粋にモード I である。

問題が軸対称問題であるので軸対称ソリッド要素を用 い，対称性を考慮して上半分のみを解析する．解析モデ ルの一例をFig. 3 に示す. $E=100 \mathrm{GPa}, \nu=0.3$,

Circular Crack

Distributed Load

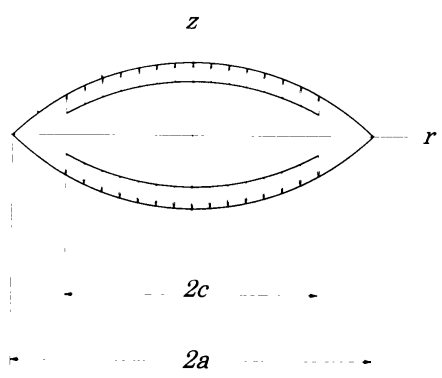

Fig. 2 A circular crack in an infinite isotropic material. A distributed load is applied in a small area at the center of the crack. 


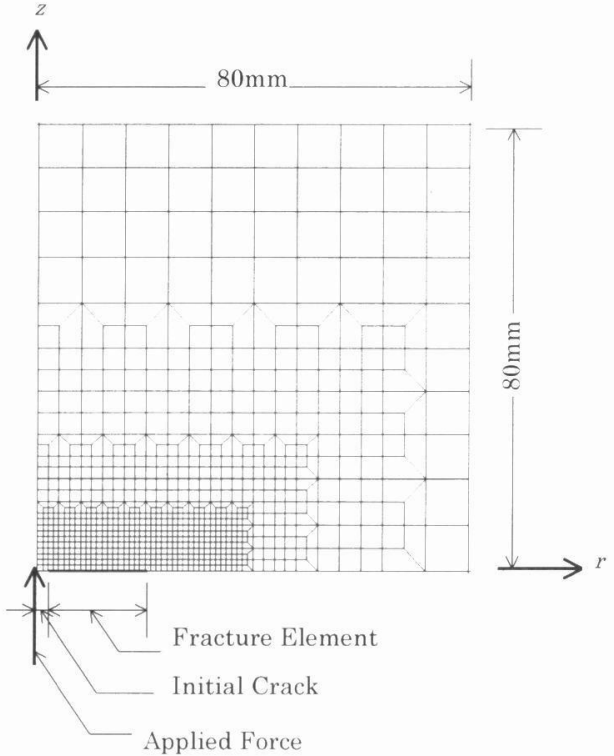

Fig. 3 A finite element model of a homogeneous axisymmetric body with a circular crack.

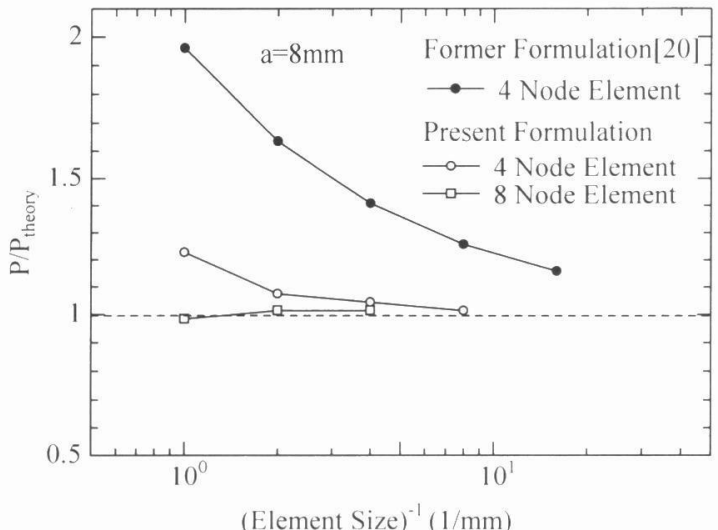

Fig. 4 Convergence of normalized forces for a crack radius of $8 \mathrm{~mm}$.

$\sigma_{c}=400 \mathrm{MPa}, G_{\mathrm{I}}=1.0 \mathrm{~kJ} / \mathrm{m}^{2}$ なる等方性無限物体中 に半径 $a=2 \mathrm{~mm}$ の初期クラックがあり, 半径 $c=1 \mathrm{~mm}$ の中心部分に一様圧力が作用するものとする。モード I のみ存在するので引張方向の非線形バネを初期クラック 先端から $r$ 軸に沿って取り付ける。

Fig. 4 にクラック半径が $8 \mathrm{~mm}$ に達するときの荷重 を線形破壊力学による理論值で正規化したものを要素业 イズに対してプロットした。比較のために前報 ${ }^{20,21)}$ の 手法による結果も併記した。前報による手法ではクラッ

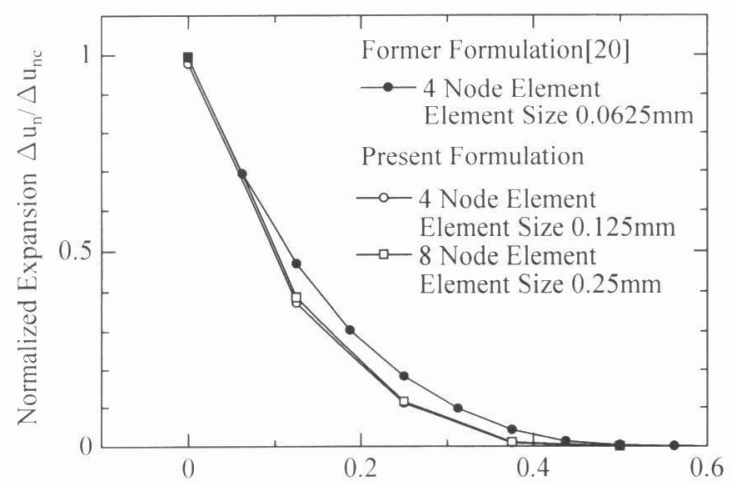

Distance from the Crack Tip Fracture Element (mm)

Fig. 5 A distributions of the expansion of fracture elements at the crack tip region.

ク先端位置に多少の不確定性を伴う. 即ち有限要素間の 境界に存在する内力の合計が節点と破壊要素を通して伝 えられると考えれば，クラックの先端は一番先端にある 破壊要素の位置ではなくそれと隣り合う既に破断した破 壊要素の位置との間にあるとするのが妥当である。ここ ではある非線形ばねが切断した瞬間においてクラック先 端は次の切断していない非線形ばねとの中間位置にある ものとした。本手法では 8 節点要素を用いた場合, 要素 サイズが $0.5 \mathrm{~mm}$ ，また 4 節点要素を用いた場合でも要 素サイズが $0.125 \mathrm{~mm}$ でほぼ完全に収束している。これ に対して前報による手法では要素サイズが $0.0625 \mathrm{~mm}$ でも完全に収束していない.これより本手法による結果 は前報による手法に比べて非常に収束が速いことが分か る. 本手法による収束値は線形破壊力学による理論値に 比べて約 3\%程度大きいがこれは破壊要素によりクラッ ク先端部の非弾性変形が生じているためである.

Fig. 5 にクラック半径が $8 \mathrm{~mm}$ の場合のクラック先 端部の破壊要素の伸び量の分布を前報の手法による結果 と共に示す。既に述べたように前報の手法ではクラック 先端位置に不確定性があるが, クラック先端の非線形バ ネからの距離に対して伸び量をプロットした. 本手法で は 1 個の非線形バネが破壊条件を満足したときに関連す る有限要素に接続された非線形バネの剛性を全てゼロと するようなモデル化を行い, その結果としてクラック進 展に伴ってクラック先端のバネのバネ定数を一般部のバ ネの $1 / 2$ にているのでクラック先端のバネ要素の変形 量が大きくなり, クラック先端から離れた位置の変形量 が相対的に小さくなっている.そのためクラック先端近 傍の局所的非弾性変形を効率良くシミュレートすること 
Table 1 Material properties of transversely isotropic plate.

\begin{tabular}{cc}
\hline \hline$E_{x}=E_{y}$ & $56.5 \mathrm{GPa}$ \\
$\nu_{x y}$ & 0.316 \\
$E_{z}$ & $9.15 \mathrm{GPa}$ \\
$\nu_{x z}=\nu_{y z}$ & 0.262 \\
$G_{x z}=G_{y z}$ & $4.18 \mathrm{GPa}$ \\
$\sigma_{c}$ & $32.6 \mathrm{MPa}$ \\
$\tau_{c}$ & $85.0 \mathrm{MPa}$ \\
$G_{I c}$ & $200 \mathrm{~J} / \mathrm{m}^{2}$ \\
$G_{I I c}$ & $400 \mathrm{~J} / \mathrm{m}^{2}$ \\
\hline
\end{tabular}

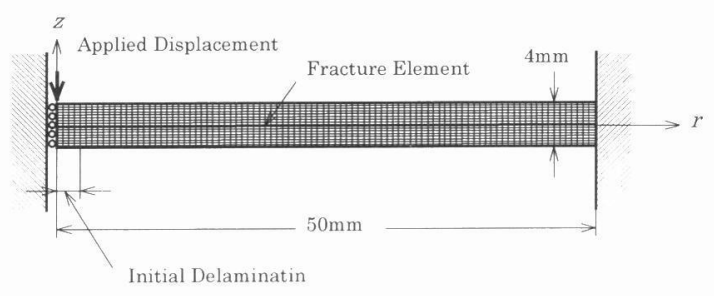

Fig. 6 A typical finite element mesh of axisymmetric composite laminate with a circular delamination.

ができる. 前報の手法で同程度の局所的非弾性変形分布 を表すためには要素分割をさらに密にする必要がある。

\section{4. 集中荷重を受ける軸対称積層板の多重層間剝離}

周辺が固定された複合材料積層円板の中央に集中荷重 を加えた場合の層間剝離進展過程を解析する，積層板は 面内等方性, 面外直交異方性の均質材料として解析し, その材料特性をTable 1 に示す。これらの材料特性は 一方向材の弾性特性から積層理論により導いたものであ る、解析モデルの一例を Fig. 6 亿示す。剥離が生ずる 面に破壊要素を導入し，中心部分に破壞状態にある破壊 要素を用いて初期剝離を与えた。集中荷重による荷重点 近傍の特異性を避けるため半径 $0.5 \mathrm{~mm}$ の板中心部表面 に強制変位を与えた。強制変位を与えた部分の反力をも って荷重とする。

最初に 1 個の剝離が板中央面にある場合について 4 節 点要素及び 8 節点要素を用いて剝離進展過程を解析し た.その結果をFig. 7 亿示す. 初期剥離は半径 $2 \mathrm{~mm}$ とした。剝離は全てモードIIで進展した。 8 節点要素を 用いた場合, 剝離先端部の要素サイズが $0.5 \mathrm{~mm}$ で完全 に収束している４節点要素を用いた場合でも剥離先端 部の要素サイズが $0.25 \mathrm{~mm}$ でほぼ収束している。前報 の手法による同じ問題の解析 ${ }^{20.21}$ (ただし， $\alpha=0.5$ と

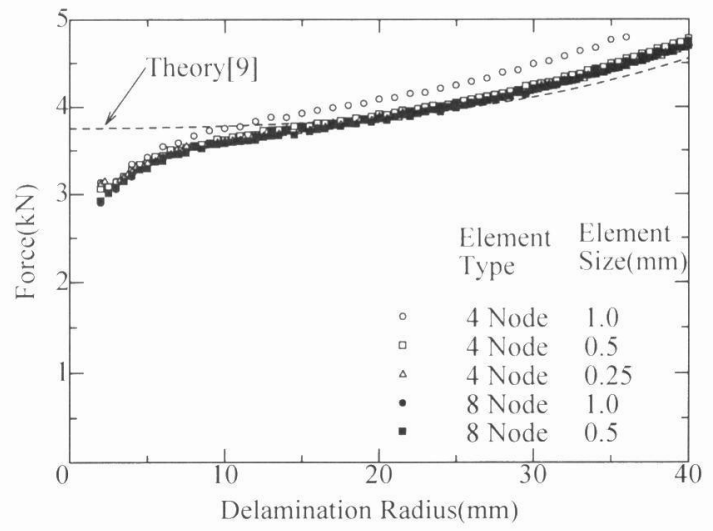

Fig. 7 Relationships between delamination radius and applied force of axisymmetric laminate with one delamination.

して解析したもの) では要素サイズを $0.0625 \mathrm{~mm}$ 程度 まで小さくしないと収束しなかったことを考慮すると本 手法による解析は非常に効率が良いことが分かる。眓に は平板曲げ理論による非線形近似解析9) の結果を併記し た。剝離半径が小さい部分では集中荷重による局所的な 変形の影響が剝離先端部に現れ, 平板曲げ理論による近 似解よりも小さい荷重で剥離が伝播する. 剝離半径が大 きくなるに従い解析結果は平板曲げ理論による近似值に 近づき, 剥離半径が約 $20 \mathrm{~mm}$ を超えると平板曲げ理論 による近似值よりも僅かに大きな荷重で剝離が伝播す る. 以下の解析は全て 8 節点要素を用いて行う.

半径が $1 \mathrm{~mm}$ または $2 \mathrm{~mm}$ の初期剝離が板厚方向に 1 $\mathrm{mm}$ 間隔で 3 個ある場合について解析を行い, 剥離半径 と荷重の関係をFig. 8 に示した. また荷重面と反対側 の面の中心点のたわみと荷重の関係を Fig. 9 に示した。 破壊要素部の要素サイズは $0.5 \mathrm{~mm}$ とした。剥離位置を 荷重面側から剥離 1 , 剥離 $2, \cdots$ のように番号を付けて 表す (以下同様)。初期剝離の大きさにより荷重点近傍 の局所的応力分布の影響が異なるため剝離進展開始時の 挙動は初期剥離の大きさの影響を強く受ける。剥離は荷 重面に近い剥離から順に進展を開始するが, 最初の剥離 進展開始は初期剝離が $2 \mathrm{~mm}$ の場合よりも $1 \mathrm{~mm}$ の場合 の方が小さな荷重で起こる，それに対して荷重面から遠 い剥離が進展を開始する荷重は初期剝離が $2 \mathrm{~mm}$ の場合 の方が小さい. 荷重面から遠い剝離が進展を開始すると きには不安定伝播を示し，そのとき他の 2 つの剝離も同 時に不安定伝播を示すと共に荷重が一時的に低下する。 その低下は初期剝離が $2 \mathrm{~mm}$ の場合よりも $1 \mathrm{~mm}$ の場合 の方が著しい，従って荷重点から遠くにある小さな剝離 


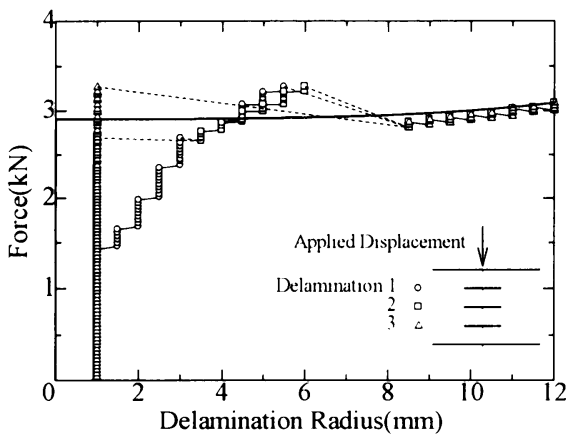

(a) Radius of Initial Delamination $1.0 \mathrm{~mm}$

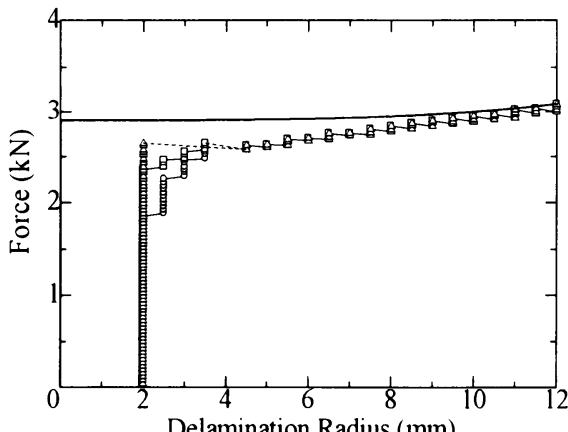

(b) Radius of Initial Delamination 2.01mm

Fig. 8 Unstable delamination propagation of axisymmetric laminate with three delaminations. stable propagation, ......unstable propagation, -

が伝播を開始するためにはかなり大きな荷重が必要であ ることが分かる．初期剝離が $1 \mathrm{~mm}$ の場合には中央面の 剥離が進展を開始するときにも不安定伝播が見られる。 Fig. 8 では不安定伝播の状況を明確に示すために全て の計算ステップにおける剥離半径をプロットした。その 結果安定伝播時において荷重と剝離半径の関係が階段状 またはジグザグ状になっている。これは本解析では剥離 先端部の局所的非弾性変形を非線形集中バネで近似し， 更に剶離先端部のバネが破壊条件に達したときにそのバ ネに接続した有限要素に関連したバネ（まだ破壊条件を 満たしていない）が全て切断されるようなモデル化を行 っているためである。バネが破断する瞬間の状態が破壊 条件を含めた系全体の力学的条件をちょうど満足してい る. 従って階段状またはジグザグ状の曲線の極大点を結 んだものが実際の荷重と剥離半径の関係になる。(なお, Fig. 7 及び後述の Fig. 10 ではバネが破断する瞬間の状 態のみをプロットした。）初期の不安定伝播終了後は荷 重の増加に伴って全ての剝離がほほ同じ大きさで進展す

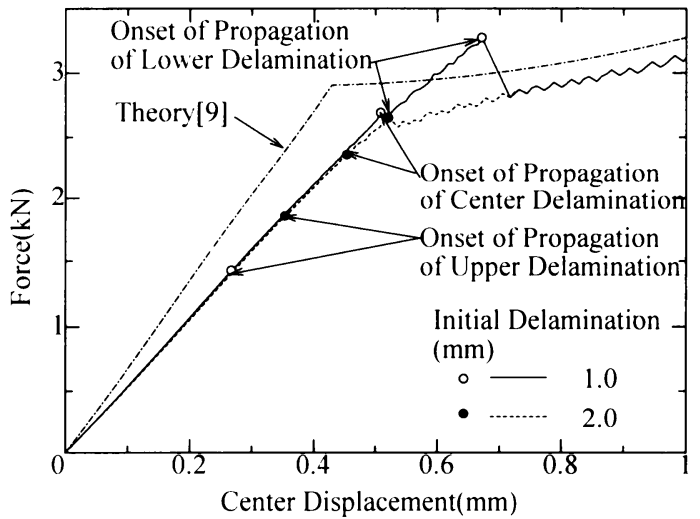

Fig. 9 Effect of the size of initial delaminations on relationships between the applied force and center displacement for the laminate with three delaminations.

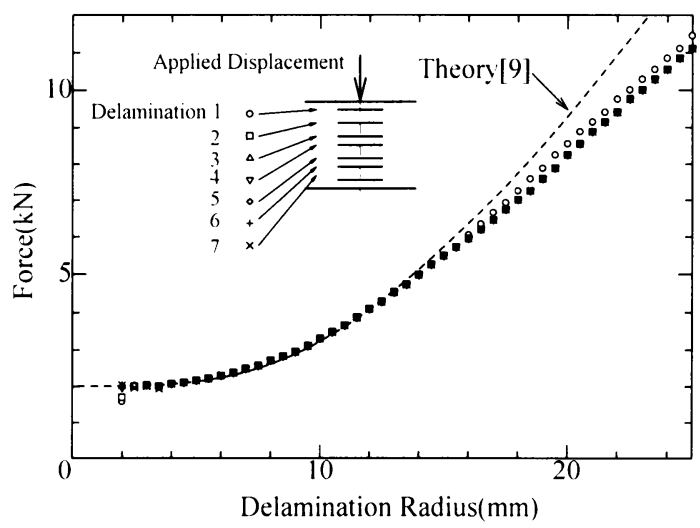

Fig. 10 Relationships between crack radii and applied force of axisymmetric laminate with seven delaminations.

る. その荷重は平板曲げ理論による非線形近似解析の結 果9)とほほ一致している.剥離伝播開始前における荷重 と変位の関係はほほ完全に線形関係を保つが，その剛性 は平板曲げ理論による近似解析結果9) との間に約 $20 \%$ の差がある．この差は近似解析では剪断変形の影響を考 慮していないためである．またこの傾きは全ての剥離が 伝播を始めるまで殆ど低下しない。

次に半径 $2 \mathrm{~mm}$ の初期剥離が板厚方向に $0.5 \mathrm{~mm}$ 間隔 で 7 個ある場合について中央点変位が板厚程度になるま で解析を行った．荷重と剝離半径の関係を Fig. 10 に示 す.要素サイズは $0.5 \mathrm{~mm}$ とした。荷重点近傍の局所的 な応力分布の影響による各剝離の大きさのばらつきは剥 離進展開始後間もなく消隇し，全ての剥離がほほほ同じ大 


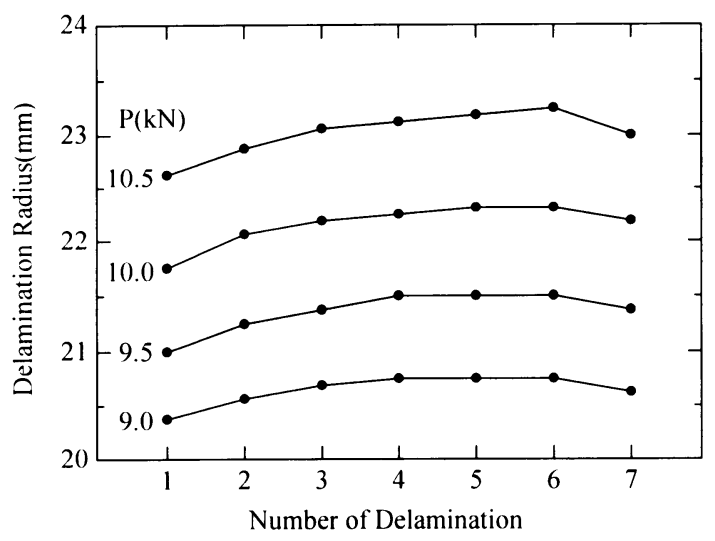

Fig. 11 Distributions of the size of delaminations of axisymmetric laminate with seven delaminations.

きさで進展する，剝離半径が $12 \mathrm{~mm}$ 程度までの解析結 果は平板曲げ理論による非線形近似解析の結果 ${ }^{9)}$ と良く 一致している。剥離半径が更に大きくなると近似解析結 果は剝離半径を小さく評価する。これは近似解析ではた わみの分布を線形解の全体変形と局所変形を表すたわみ 関数で 2 項近似しているため変位が剥離片の板厚に比べ て大きくなり線形解と変形形状が異なってくると, 剥離 部のたわみ分布を適切に近似することが困難になり，工 ネルギー解放率が過小評価されるためと思われる.

Fig. 10 の結果では荷重の増加に伴って各々の剥離の 大きさに若干の差が認められる、剥離の大きさの分布は 興味のある点であるが, 本解析では剝離先端部の要素サ イズ程度の精度以上に評価できない.そこで半径約 $20.3 \mathrm{~mm}$ の初期剝離を与えて剝離先端部の要素サイズ を $0.0625 \mathrm{~mm}$ として解析し, 剥離の大きさの分布の履 歴を求め, その結果を Fig. 11 に示した.この分布形状 は剥離先端部のエネルギー解放率の分布" ${ }^{9)}$ から推定され る分布形状と一致し, 荷重が大きくなると剥離の大きさ が最大になる位置が荷重面と反対側の方向に移動する傾 向にあることを示している. しかしその差は非常に小さ くFig. 11 の結果は積層板の衝撃試験において観測され る多重層間剝離の分布（荷重面から反対側の面に向って 大きくなるいわゆる円錐状分布となる ${ }^{6)}$ )を裏付けるほ どの顕著な結果を示していない. 積層板の実際の層間剥 離はトランスバースクラックを始めとする層間剝離以外 の損傷と互いに連成しながら進展しているので積層板の 実際の損傷挙動をより適切にシミュレートするためには 層間剝離以外の損傷パターンについても考慮する必要が ある。

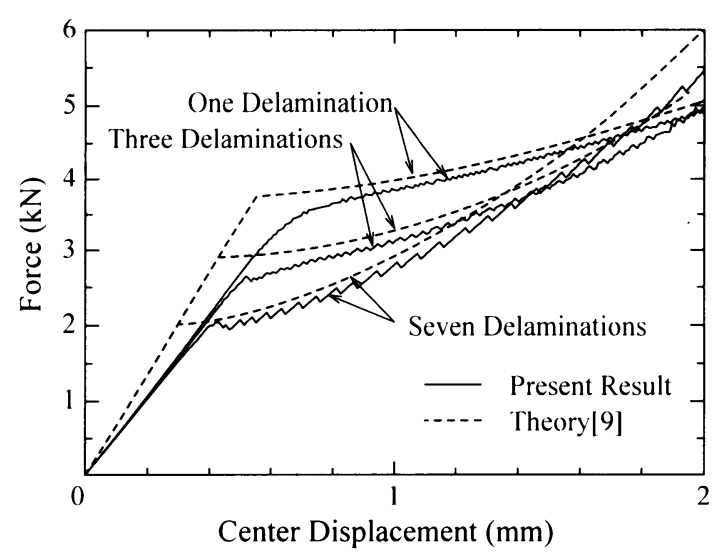

Fig. 12 Effect of the number of delaminations on relationships between center displacement and applied force of axisymmetric laminate with delaminations.

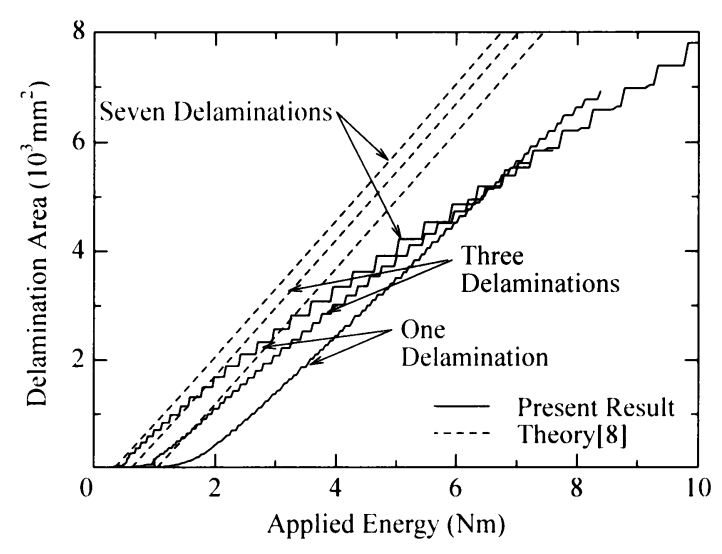

Fig. 13 Effect of number of delaminations on relationships between applied energy and delamination area of axisymmetric laminate with delaminations.

剥離数が 1 個, 3 個, 7 個の各場合について荷重と中 央点変位の関係をまとめて示したのが Fig. 12 である. 図には平板曲げ理論による非線形近似解析の結果 ${ }^{9)}$ を併 記した。また同様の場合について荷重のなす仕事と剥離 面積の関係を平板曲げ理論による線形近似解析の結果 ${ }^{8)}$ と共に Fig. 13 に示した. 初期剝離は $2 \mathrm{~mm}$ とした. 剥 離伝播開始後において曲線がジグザグ状になっているの はFig. 8 と同様の理由による. 従ってジグザグ状の曲 線の極大点を結んだものが実際の平衡曲線及び荷重のな す仕事と剥離面積の関係になる，剝離伝播開始前におい て平衡曲線と平板曲げ理論による近似解析結果との間に 
差が生ずるのは近似解析では曲げによる剪断変形を考慮 していないことによる．また剥離の伝播開始のために必 要なエネルギーの近似解との差は荷重点の局所的な変形 と剪断変形によって荷重点の変位が大きくなるために, 同じ大きさの集中荷重によってなされる仕事が大きくな るためである. 剥離伝播開始後, 荷重は特に剥離部の幾 何学的非線形性により緩やかに増加するが剥離数が多く なるほど剥離片の幾何学的非線形性が顕著になり，たわ みの増加に従って剛性も増加する。 その場合, 近似解析 では既に述べたようにたわみの分布を曲げのたわみ関数 で近似しているため剛性が過大評価され，本解析結果と の差が大きくなる。この别離片の幾何学的非線形性のた めに相対的に多くのエネルギーが変形のために消費さ れ, 剝離の進展を進めるためにはより多くのエネルギー を供給する必要がある. 従って単位剥離面積の伝播に必 要なエネルギーは線形近似解析では剝離数, 剥離の大き さにかかわらず一定であるが，非線形性を考慮した本解 析結果は剝離数が多い程, また剝離が大きくなる程多く のエネルギーが必要となる.

\section{5. 結論}

有限要素の形状関数を考慮して破壊要素特性を決定 し, 有限要素単位で破壊条件を適用するようなモデルを 提案し, 前報の手法に比べて解の収束性を格段に向上さ せることができた。

本手法を集中荷重を受ける準静的な軸対称円形積層板 の層間剝離伝播問題に適用し, 前報による手法では多大 の解析労力を必要とし解析が困難であった幾何学的非線 形性を考慮した多重層間剝離問題の解析を行うことがで きた。その結果は平板曲げ理論に基づく非線形解析結果 と良く一致し, 両者が共に正しいことが確認された。積 層板の剶離伝播挙動に対する幾何学的非線形性の影響は 主に剥離片の幾何学的非線形性によって支配されるため 特に剝離数の多い程重要であることが分かる. 剥離進展 開始直後に見られる不安定伝播挙動を十分にシミュレー トすることができた，積層板の衝撃試験においてしばし ば観測される多重層間剥離の大きさは裏面に向って若干 大きくなる円錐状分布となるが，この現象はトランスバ 一スクラック等との連成が重要な要因となっており, 層 間剝離のみを考慮した本解析では完全に説明することが 困難であることが分かった。

本手法はクラック先端の非線形バネが破壊条件に達し たときにそのバネが接続された有限要素に関連した全て のバネ（破壊条件に達していない）を切断するようなモ
デル化を行っているので破壊時に破面形成のために消費 されるであろうエネルギーをクラック先端のバネ要素を 除いて完全に吸収させることができない. 従って破面形 成時に消費されるエネルギーを考慮しなければならない 動的問題にこのまま適用することはできない。この点を 解决することが今後の課題である。

\section{参 考 文 献}

1) H.Y.T. Wu \& G.S. Springer : J. Composite Materials, 22, 6 (1988), 518-532.

2) W. Elber : NASA Technical Paper, 2152 (1983).

3) S.M. Lee \& P. Zahuta : J. Composite Materials, 25, 2 (1991), 204-222.

4) H.Y. Choi, R.J. Downs \& F.K. Chang : J. Composite Materials, 25, 8 (1991), 992-1011.

5) P. Robinson \& G.A.O. Davies : Int. J. Impact Engineering, 12, 2 (1992), 189-207.

6) T. Ishikawa, S. Sugimoto, M. Matsushima \& Y. Hayashi : Composite Sci. Tech., 55 (1995), 349353.

7) H. Suemasu \& M. Maier : Adv. Composite Materials, 5, 1 (1995), 17-33.

8) H. Suemasu \& O. Majima : J. Composite Materials, 30, 4 (1996), 441-453.

9) H. Suemasu \& O. Majima : J. Composite Materials, 32, 2 (1998), 123-140.

10) H.Y.T. Wu \& G.S. Springer : J. Composite Materials, 22, 6 (1988), 533-560.

11) H.Y. Choi, H.Y.T. Wu \& F.K. Chang : J. Composite Materials, 25, 8 (1991), 1012-1038.

12) Y. Shimamura, A. Todoroki, H. Kobayashi \& H. Nakamura : Proc. 7th Japan-U.S. Conf. Composite Materials, Kyoto (1995), pp. 57-62.

13) T. Tsumura, M. Zako, N. Takano \& T. Tsujikami : Proc. 7th Japan-U.S. Conf. Composite Materials, Kyoto (1995), pp. 69-74.

14) B.V. Sankar \& S. Hu : J. Composite Materials, 25, 11 (1991), 1414-1426.

15) C.T. Jih \& C.T. Sun : J. Composite Materials, 27, 7 (1993), 684-701.

16) H. Razi \& A.S. Kobayashi : AIAA J., 31, 8 (1993), 1498-1502.

17) S. Liu \& F.K. Chang : J. Composite Materials, 28, 10 (1994), 940-977.

18) S. Kamiya, H. Sekine \& Y. Yagishita : J. Composite Materials, 32, 8 (1998), 744-765.

19) Y.M.M.A. Crisfield \& G.A.O. Davies : J. Composite Materials, 32, 14 (1998), 1246-1272.

20）間島 理，末益博志：日本複合材料学会誌， $25 ， 4$ (1999), 140-148.

21) H. Suemasu, O. Majjima \& Y. Aoki : J. Rein forced Plastics and Composites, 18, 12 (1999), 1156-1169. 